\title{
Curating Action: Rethinking Ethnographic Collections and the Role/Place of Performing Arts in the Museum
}

\author{
Hélène Bernier, Mathieu Viau-Courville
}

\begin{abstract}
Dance involves a set of movements that embody social memory. Such forms of intangible heritage have presented emerging challenges for curatorship. This paper draws from the experience of the Musées de la civilisation (Quebec City, Canada) to address ideas of collecting and curating in the performing arts. By presenting the travelling exhibition Rebel Bodies, an international collaborative project that highlights contemporary dance and movement as universal modes of creativity and expression, the paper reflects on the social role of the museum in sustaining creativity within the community as well as on the use of ethnographic material to collectively (through museums and artists) curate the intangible. In treating notions of natural, virtuoso, urban, multi, political, and atypical bodies, this exhibition brings together performers and creative artists as well as industries in the museum setting. Such interplays, it is argued, encourage the sustainable participation of artistic communities/industries and further highlight museums as dynamic loci for the promotion of social change.
\end{abstract}

Keywords: performing arts, intangible cultural heritage, museum, dance, performance, participation, reenactment, artists

\section{Introduction}

The notion of performance in museum studies, as in the social sciences and humanities in general, has become an important topic in recent years by highlighting the central role of visitors' actions in the production of meaning (Robertshaw 2006; Bal 2011; Jackson and Kidd 2011; Macdonald 2011:2; Christidou 2012). Facilitated by the use of digital technologies, interactive media and intricate sound and light installations, some museums have indeed transformed into 'ever-changing theatre scenes' (Alivizatou 2011:82). In this context, performance is seen not only as a mode of communication and meaning-making, but also as a mode of social action. Such developments can be understood against the backdrop of participatory practice and collaboration (Kreps 2003, 2009; Simon 2010; Golding and Modest 2013) and cultural democratization (Karp, Kreamer and Levine 1992; Sandell 1998), which have progressively placed human agency at the centre of institutional preoccupations. As a result, the focus of some museums has shifted from objects to subjects-and specifically to the 'experience' of visitors as a fundamental element in understanding heritage (Frey and Kirshenblatt-Gimblett 2002; Jackson and Kidd 2011:1; Macdonald 2011).

In parallel, UNESCO's 2003 Convention for the Safeguarding of Intangible Cultural Heritage, along with subsequent international initiatives such as the 2004 General Conference of the International Council of Museums (ICOM) in Seoul that further reflected on the application of the Convention into museum practice, have been useful to museum practitioners and theorists in reconsidering intangible cultural heritage $(\mathrm{ICH})$ as embodiments of cultural and social memory (Hooper-Greenhill 2000; Smith 2006; Alivizatou 2008, 2013; Ruggles and Silverman 2009). This focus on subjects rather than on objects provides further opportunities for rethinking the use, relevance, and role of ethnographic collections in today's performance-oriented heritage sector. This paper offers a fresh perspective on the use of ethnographic material by examining the case

Museum \& Society, July 2016. 14 (2) 237-252 (c) 2016, HélèneBernier, Mathieu Viau-Courville. ISSN $1479-8360$ 
of the Musées de la civilisation ${ }^{1}(\mathrm{MCQ})$ in curating $\mathrm{ICH}$. It describes the contemporary dance project Corps rebelles/Rebel Bodies, a collaborative exhibition that addresses intersections among heritage interpretation, contemporary dance and exhibition-making. Inaugurated in March 2015, the project has involved local performance artists (and industries) in participating and contributing to the process of meaning-making. The aim has been to turn both artists and visitors into active participants who contribute in a collective effort to reinterpret and transform ideas related to the performing arts, while also effecting change in the museum.

\section{Curating the intangible}

Performing arts such as dance involve sets of movements and behavioural patterns that embody a form of social memory (Connerton 1989; Schechner 2003). By seeing human movement itself as a type of heritage, Rebel Bodies approaches bodily action as an essential component of $\mathrm{ICH}$. The exhibition space is transformed and presented to visitors as a kind of immersive theatre setting. Like a theatre stage, the exhibition is thought of as a site that involves an audience that observes and evaluates. But just as theatrical performances are aimed at a separate audience, the exhibition aims to progressively transform the visit into a shared action, and in this sense becoming more like a ritual action (Schechner 2003). And just like any kind of ritualized behaviour, the participants mutually learn how to move and position themselves within the ritually-defined space (Bell 1992; Goffman 1959; Schechner 2003).

As sociologist Paul Connerton (1989:40) has argued, it is through participation that 'images of the past and recollected knowledge of the past are conveyed and sustained by (more or less ritual) performances'. In the performing arts, then, and as one of several postulates behind Rebel Bodies, bodily action re-enacts and 're-presents' cultural values. This resonates with what Connerton (1989:69) (echoing Lévi-Bruhl) describes as the 'reappear[ance] [of] that which has disappeared' or what Halifu Osumare, in her study of hip hop culture in Hawaii, described as '...acts that bring forth, through the body, what has been previously invisible, submerged in the psyche' (Osumare 2013:261). Rebel Bodies approaches heritage not as a material 'thing' or a material object, but rather in similar terms to those offered by Laurajane Smith - as a "cultural practice, involved in the construction and regulation of a range of values and understandings' (Smith 2006:11). It is this 'cultural practice' that Rebel Bodies aims to highlight. The exhibition itself, it is argued, becomes an (ethnographic) 'object' or 'artefact'. The ethnographic material as defined here may stray from the typical anthropological perspective which encompasses 'non-Western' artefacts and whose source communities have oft been marginalized. For the purposes of this paper, and perhaps in a slight departure from other contributions in this special issue of Museum and Society, 'ethnographic material' will rather comprise the sets of photographic and video archives (seen as artefacts) and other material objects related to and further highlighting the ethnography of dance. Here 'ethnographic' is closely related to ethnicity and nationalism in terms of the cultural, historical, and political circumstances that contributed to the development of dance in Quebec and/or Canadian populations, culture and history. The definition stems from the Musées de la civilisation's vision toward an inclusive and community-driven approach to museum practice and exhibition-making, which has sought to eliminate existing barriers between categories of objects. This has followed trends in some museums' retreat from any singular or dominant academic paradigm, or specialization such as a museum of anthropology, of ethnography, or art (see Shelton 2011: 76). ${ }^{2}$ As noted by Boylan (2011: 418), 'perhaps museums' retreat from scholarly curatorship contributed in boosting the social role and potential of museum institutions, in North America and elsewhere.' In such a context, and following a broad conception of civilization, ethnographic materials include all forms of material traces of society. As a musée de société ${ }^{3}$, the MCQ museum complex examines notions of society and cultural citizenship from a thematic and multidisciplinary point of view. A product of French-Canadian New Museology thinking and practice that developed in Quebec during the $1980 \mathrm{~s},{ }^{4} \mathrm{MCQ}$ has aimed at being as much a place of enchantment as one of the celebration of knowledge; a place that encourages and promotes collective enquiry. Its cultural mission is to have a social impact that extends beyond a single visit. It seeks to build relationships with its visitors and communities over time whilst progressively (and collectively) working toward a community-driven museum practice (Côté 2012). 
Rebel Bodies has been an opportunity to reflect on the use and validity of ethnographic materials as effective means through which dance is mediated, most notably through video and photography (see, e.g., Greenfield 1998; Taylor 1998). Such an approach is particularly useful in a theme-based museum like the Musées de la civilisation, where traditional collectionsbased research has been set aside in order to develop and continuously probe new forms of transmission and communication of knowledge informed by principles of a multi-vocal museology. While most MCQ exhibitions have relied on objects to illustrate narratives, more recent projects have explored the potential use of video and sound archives (approached as artefacts). A recent example is the exhibition on Quebec author and playwright Michel Tremblay that was entirely built without objects (from museum collections), favouring instead a total visitor immersion in videos to highlight the author's creative and imaginative universe

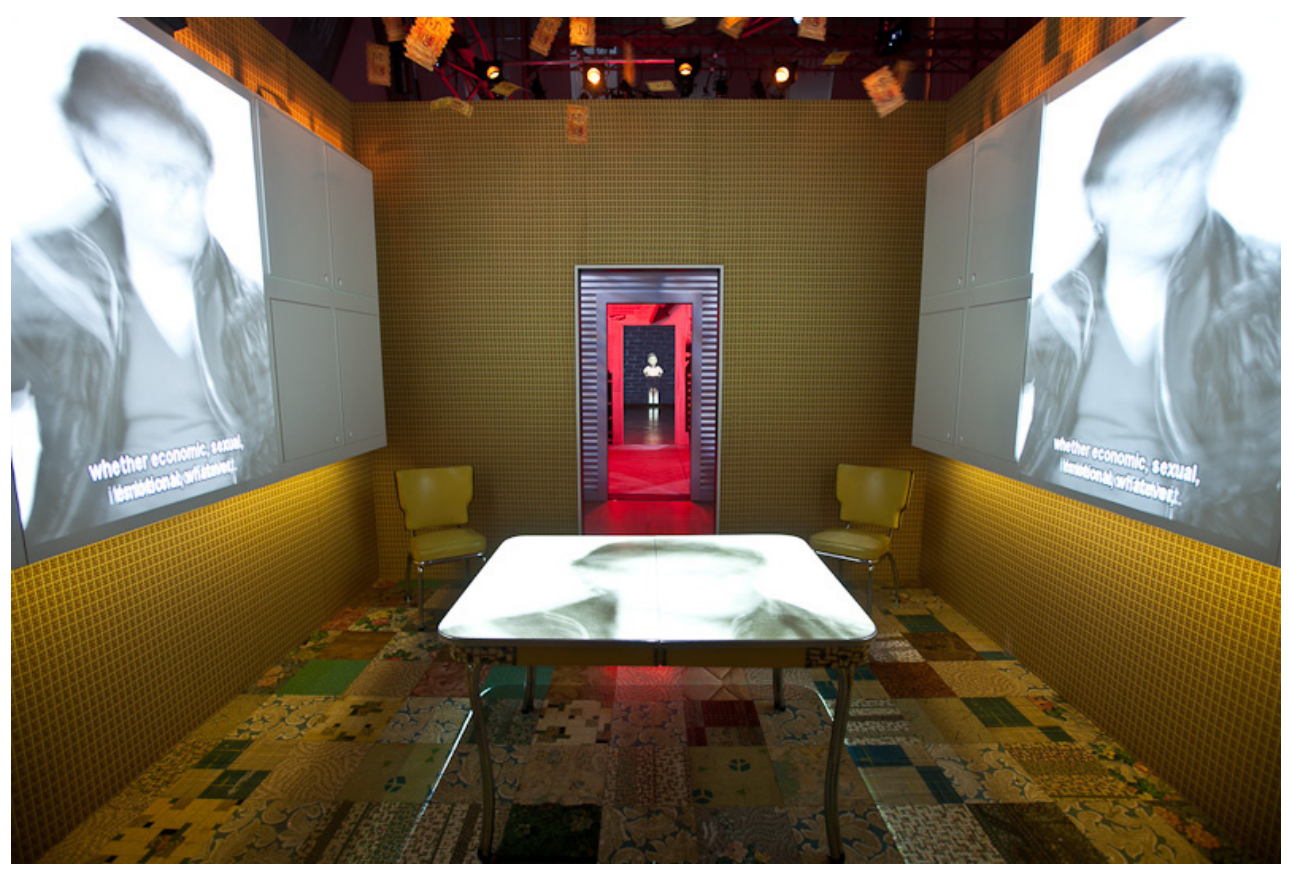

Figure 1. Michel Tremblay exhibition, March 14, 2012 to August 18, 2013 (Musées de la civilisation. Photo: Nicola-Frank Vachon - Perspective Photo)

Rebel Bodies goes further in testing such 'non-objects' exhibitions by treating the human body as an artefact - the (material) heritage to be curated and displayed, in this case for and with artists and visitors.

\section{Curating action}

Because traditional museum practice has focused on the preservation of material culture, theme-based museums are confronted with the challenge of providing continued access to as well as highlighting the use and relevance of - collections, while also focusing on ICH in its key areas. These include the performing arts, oral traditions, social practices, knowledge and practices concerning nature and the universe, and traditional craftsmanship (UNESCO 2003). The MCQ's recent series of exhibition projects is aimed at rethinking the use of ethnographic material in the service of contemporary ICH. Like other institutions, the MCQ has been increasingly concerned with the future and lifespan of their accumulated (and accumulating) ethnographic collections. Once an artefact has been selected, displaced from its original context, and has reached the status of a singular museum object, what will become of it_- and for how long? 
Some museum projects have proposed various ways to display and highlight their collections. For example, Big Bang (2011), presented by the Montreal Museum of Fine Arts, displayed various original temporary installations by contemporary artists in the rooms that usually house the Museum's permanent collections. Similarly, the Museum of Ethnography of Neuchâtel (MEN) explored in Le Musée cannibale (2002-2003) how the upsetting of the set boundaries between categories of objects in the MEN's ethnographic collections 'bear[s] witness to the desire to incorporate what is different, or other' (Gonseth and Yasgi 2002).

Some of the recent MCQ projects also re-examine the use of exhibition spaces in a museum for the purposes of artistic expression, community participation, and social change. Inspired by similar projects in Europe, some exhibitions have tested the possibility of providing Quebec and international artists with access to MCQ spaces and collections. This enhances the idea that such participatory practices can greatly contribute to improving the visibility of museum collections and renew interest and perspectives on the artefacts that compose them. Diane Landry - Correspondences (2012) addressed the role and relevance of an ethnographic museum in engaging contemporary art, a role traditionally reserved for art museums. Presented in 2012 at the Musée de l'Amérique francophone (then, Musée de l'Amérique française), a component of the MCQ complex that aims to highlight Francophone culture in North America, the exhibition centred on visitor performance in relation to installations created by Quebec City-based contemporary artist Diane Landry. The premise, while not entirely new to the global museum scene, was relatively straightforward: 1) invite a guest curator from the contemporary art community to visit the MCQ collections and select an object which will serve as a prelude to the exhibition; 2) invite a local contemporary artist to participate in and contribute to the project. ${ }^{5}$ Guest curator Nicole Gingras selected an old snowmobile from the Museum's transport and technology collection. The artefact was placed at the entrance of one of the exhibition halls of the Museum. Taking the snowmobile as basis for inspiration, Landry was invited to place some of her previous art installations, and create an entirely new one for the purposes of the exhibition. The project was meant to challenge the nature and role of an ethnographic museum, momentarily transforming it into a place for contemporary art where local artists are invited to make use of ethnographic collections as a means for artistic expression (Viau-Courville 2012). The project was a first step in bringing creators into the Museum, and rethinking creativity in the museum generally. The challenge was to channel museum creativity within the strictly confined boundaries of an exhibition space. This was meant to encourage collaboration between artists and museum staff (conservators, educators, designers, etc.), and not act solely as a museum institution that simply lends its spaces to creators. Rebel Bodies takes the idea further with the aim of engaging performance and creative artists (and industries) in an $800 \mathrm{~m}^{2}$ exhibition space.

Acknowledging the relevance of memorial or anthropological approaches to heritage and experiencing the past, as opposed to Eurocentric understandings of heritage (Butler cited in Alivizatou 2008:48), Rebel Bodies curates the bodily action (human movements and gestures) of participating artists and participating visitors. Using the body itself as heritage, the exhibition, in and of itself, is seen as a collectively curated 'artefact'. The exhibition is to become a stage on which projects are created and curated in action; a place where visitors get a sense of the impact of their own bodily actions-how our movements can effect change in the world.

\section{Experiencing Rebel Bodies}

Rebel Bodies is an international pilot project initiated by the Musées de la civilisation, in partnership with the Musée des Confluences (Lyon, France) and Moment Factory (New Media studio, Montreal). The project brings together museum visitors and members from the contemporary dance community. Going through the exhibition, visitors get a sense of the ways in which the movement of a dancing body can become a means by which the body becomes social - that is, a medium for political resistance and social change. Our actions can effect social change. Parallels are drawn between given historical and political contexts and contemporary dance. Visitors are taken beyond the expected museum experience and are encouraged to think and act with their bodies rather than with their minds.

The exhibition is arranged into seven zones that progressively transform the visit 


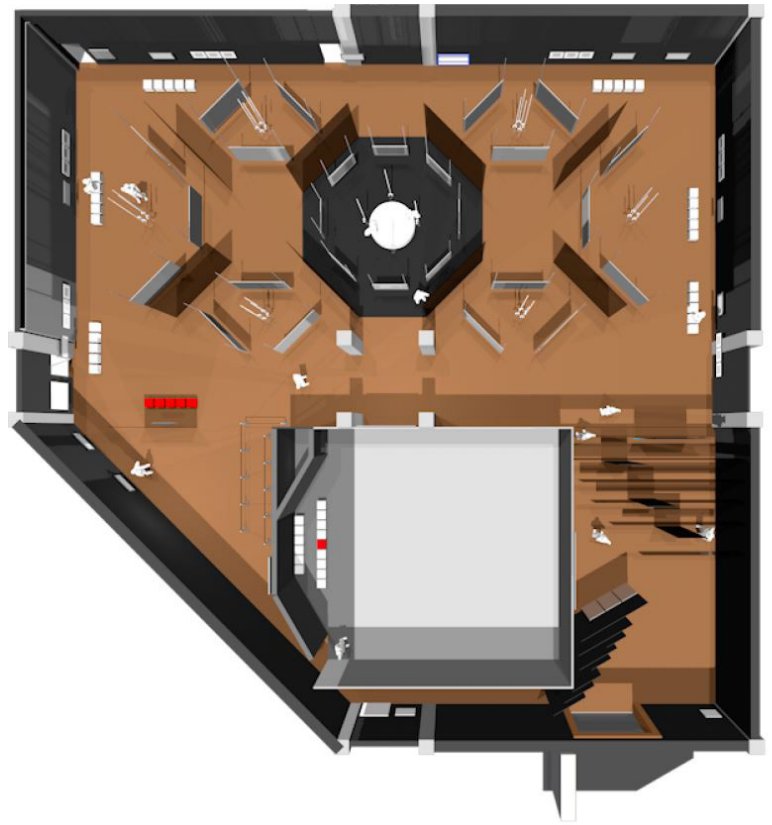

Figure 2. Computer-generated perspective view of Rebel Bodies (Design: Musées de la civilisation/Moment Factory)

Audio headsets made available at the beginning of the visit also provide additional information in the form of narrated content and music tracks. The audio content progressively adapts as the visitor goes through the various sections of the exhibit. Short texts provide the basics of the various forms of dance used as tools of political and ideological resistance.

The six 'states' of the choreographed/social body that develop through the exhibition are defined as:

- Natural bodies: Creators and/or manifestations that link body and nature, exploring the organic nature or primitiveness of the body;

- Virtuoso bodies: Creators and/or manifestations that push the limits of the human body, in terms of comprehension and execution of bodily gestures;

- Urban bodies: Creators and/or manifestations that further bridge body and city, and more broadly, the modernization of daily routine;

- Multi-bodies (technological or multidisciplinary): Creators and/or manifestations that modify the presence or resonance of the bodies in time and space using new technologies and interdisciplinary approaches;

- Political bodies: Creators and/or manifestations whose impact is clearly politically engaged, as active protest;

- $\quad$ Atypical bodies: Creators and/or manifestations that transform the body's state either metaphorically or physically, in its nature or its structure, thus affecting the way the body moves, often in atypical forms (morphological differences, disability, and so on).

Zone 2 looks at contemporary dance, its turning points in time and famous artists that pioneered the art from that of modern dance to contemporary dance. Monumental theatre-style curtains 
provide insight into the basis of contemporary dance: definitions, history, key concepts in screenplay, authorship, specific codes in dancing as well as genres of social dances that make the body social.

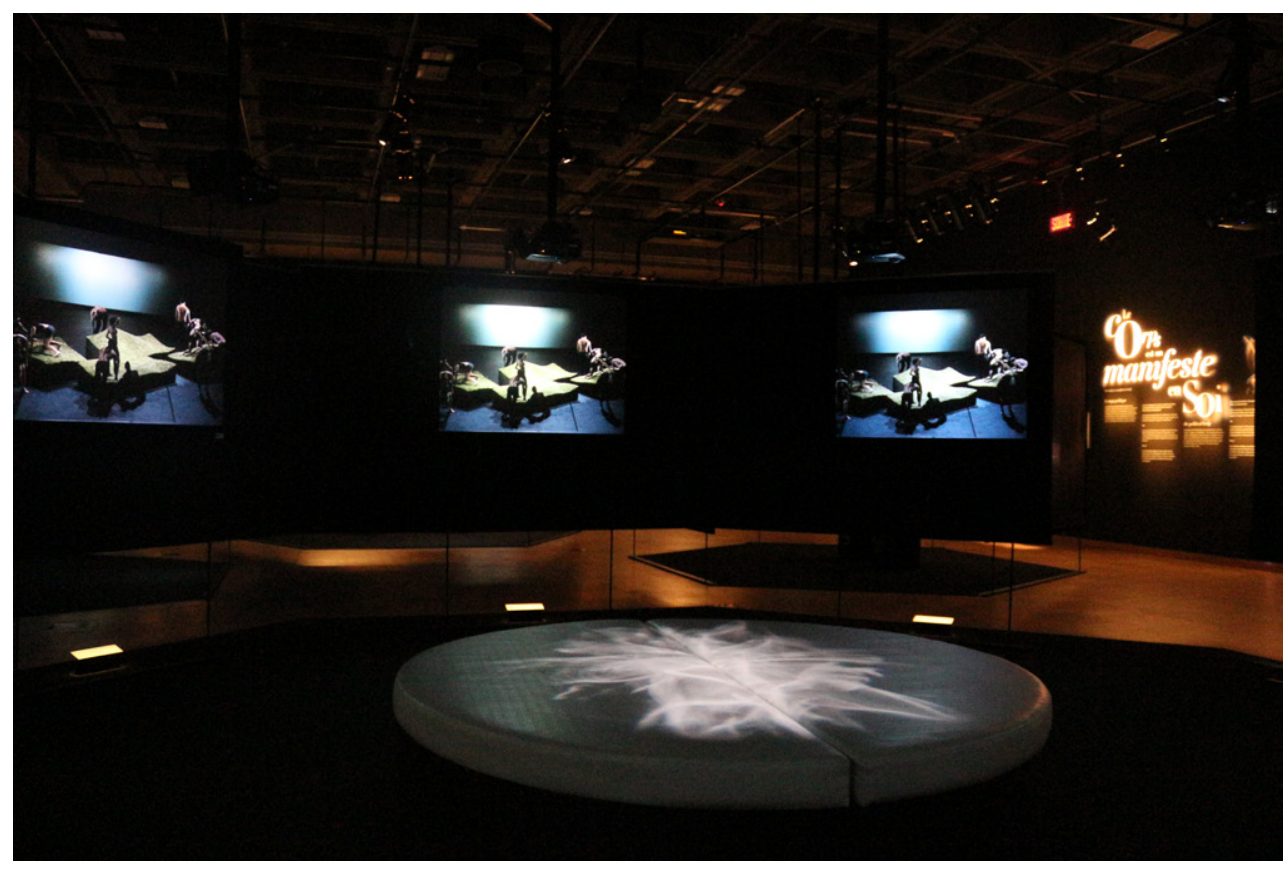

Figure 3. The Rite of Spring installation in Rebel Bodies (Musées de la civilisation. Photo: Audrey Brossard)

Zone 3 is a monumental eight-screen circular installation that invites visitors to sit on a circular sofa and experience Stravinsky's The Rite of Spring. The eight screens display, one by one, eight of the many available reinterpretations of The Rite of Spring. The installation demonstrates how the re-enactment of a particular performance over time can significantly change in light of social and political transformations (e.g., changes in the place of women in society, homosexuality, changed perceptions of aesthetic values, etc.). Composed and choreographed at the height of the Parisian Belle Époque, The Rite of Spring nearly triggered a riot when it was first performed at the Théâtre des Champs-Élysées in 1913. Its procession of disjointed, shuffling movements coupled with strident, blaring rhythms shocked the audience. The Rite of Spring nevertheless became a powerful vehicle for expressing fantastical ideas and has since been reinterpreted and performed over two hundred times. While the essence and meaning of The Rite of Spring have remained very much present in collective memory, very few material objects from the original work have been preserved; these include the original score, some photographs, drawings from an artist/audience member, and a few notes on movement.

With its many transformations and reinterpretations, The Rite of Spring constitutes a key example for the many challenges it presents in terms of curatorship (especially since no costumes, props, or elements of décor have been preserved). In particular, it highlights issues related to optimal ways of preserving and curating the performing arts - especially when, as it is being argued here, there is a particular interest in ensuring the survival of its memory through constant recurrence, renewal and reinvention.

Zone 4 develops each of the six choreographed bodily states introduced at the beginning of the visit. Each state is identified, created, choreographed and curated in collaboration with contributing partner artists. ${ }^{6}$ Each one is then presented as an immersive unit composed of three giant screens that surround the visitor (Figures. 4-5).

Each unit was fully developed and performed by one of the project's artists, who first worked 


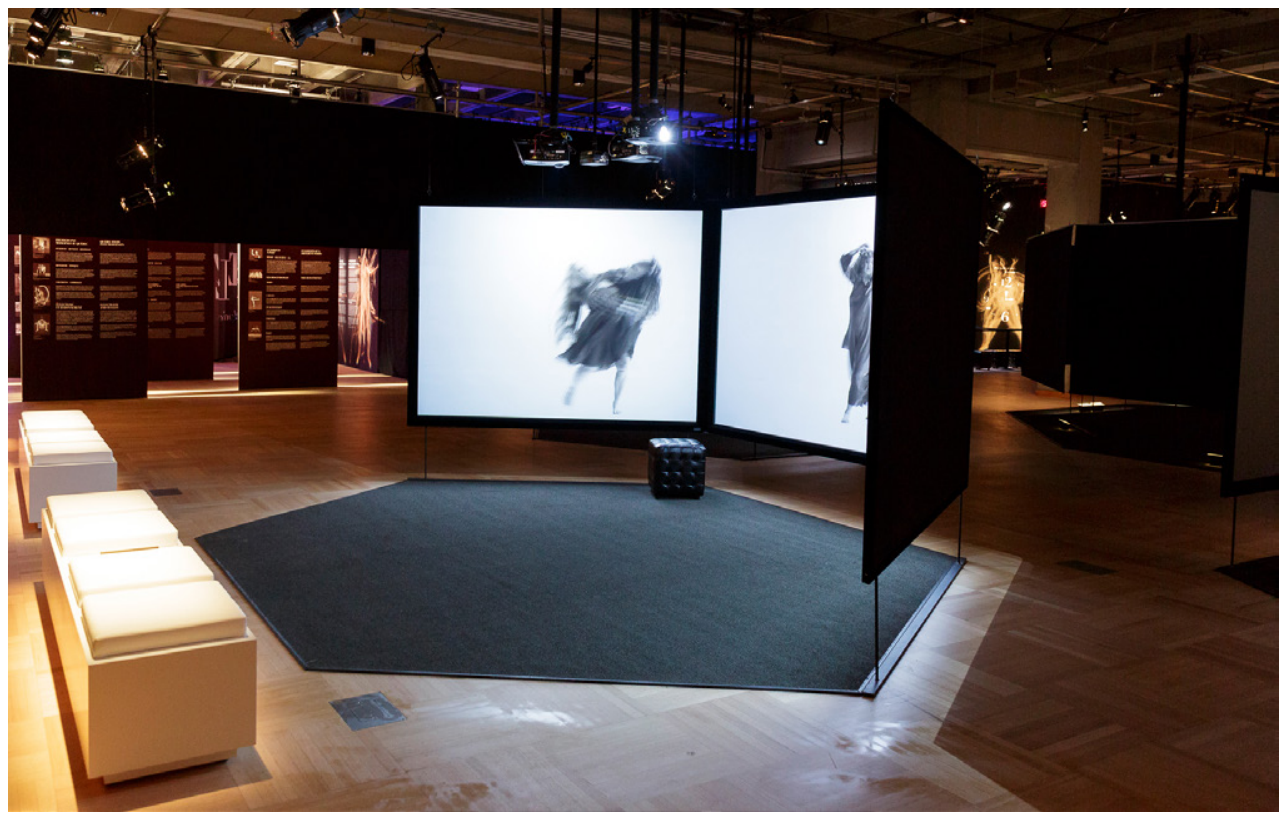

Figures 4-5. Views of the exhibition's immersive units, each developed in collaboration with partner artists (Musées de la civilisation. Photo: Jérémie LeBlond-Fontaine - Icône)

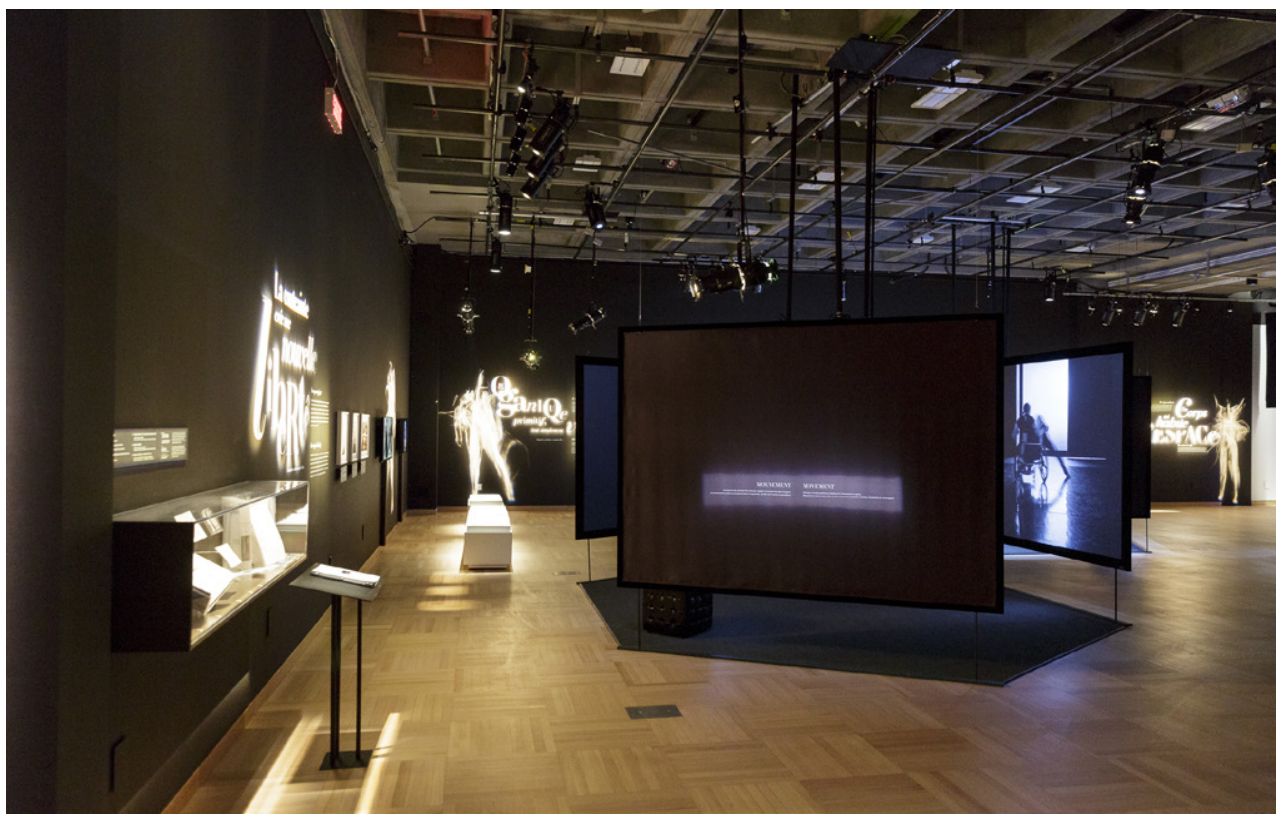

with $M C Q$ staff to develop the narrative and explore each bodily state. Once a narrative had been constructed, the artist was interviewed for a documentary-style video. Next, all the artists gathered in one of the Museum's spaces and each performed in front of the camera filming each of the states 


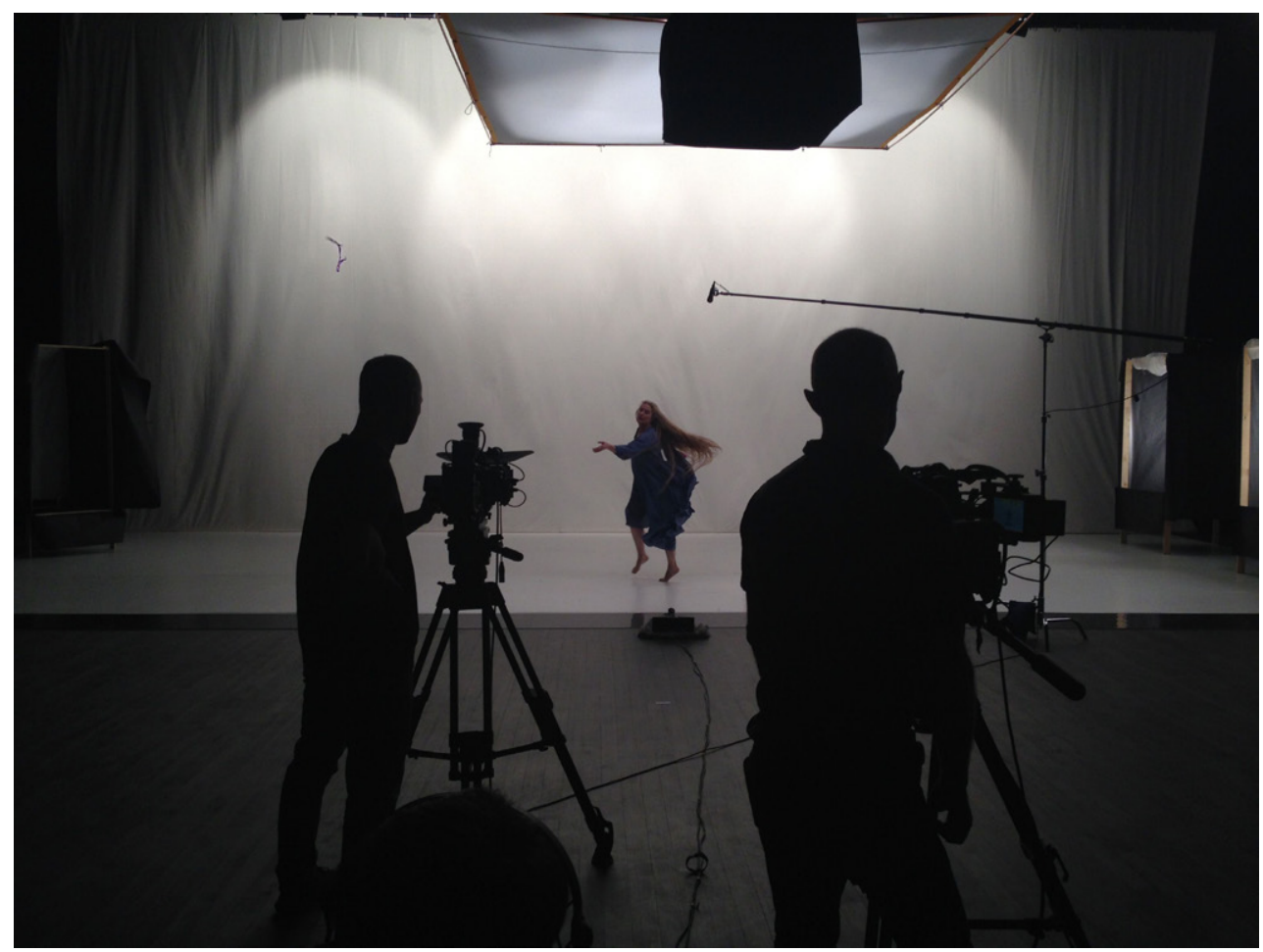

Figure 6. Artist Margie Gillis performing during video shoots at the Musée de la civilisation (Musées de la civilisation. Image courtesy of Margie Gillis)

Snapshots of the storyboard created by the artists and MCQ staff were also included in the final projections and showed on screen in order to illustrate the creative process during performances. The final edited versions made available to visitors link the artist interviews, the filmed performance and storyboards, with added cinematographic effects - all of which provide an inclusive audiovisual interpretation for each bodily state.

Zone 5 is comprised of consultation posts adjacent to zone 4, along the exhibition lateral walls. The six consultation posts (each seating six visitors) display short video clips (three minutes) of live performances recorded around the world. Each post is grouped thematically based on one of the bodily states, with examples from artists, and accompanied by their biographies. Video and photographic archives of dance performances are showcased on the walls between the consultation posts.

Zone 6 serves as an interlude. It emphasizes the ephemeral nature of contemporary dance and creativity. A small section of the exhibition that gathers recent tools developed by members of the Quebec dance community in order to record both the tangible and intangible traces of contemporary dance. Examples of objects on display include annotation systems, notes taken by creators and excerpts from dance manuals, choreographic boxes produced by the Fondation Jean-Pierre Perreault containing various elements necessary for the recreation of a choreographic work along with video systems specifically designed to capture and record human movements.

The final zone, the Studio, reproduces a $\sim 100 \mathrm{~m}^{2}$ dance studio that transforms the exhibition into a place of creativity and performance. This is done through two types of activities. The first invites visitors at the end of their visit to experience full immersion in Joe, a musical play written in 1983 by Quebec dancer and creator Jean-Pierre Perreault (1942-2002). 


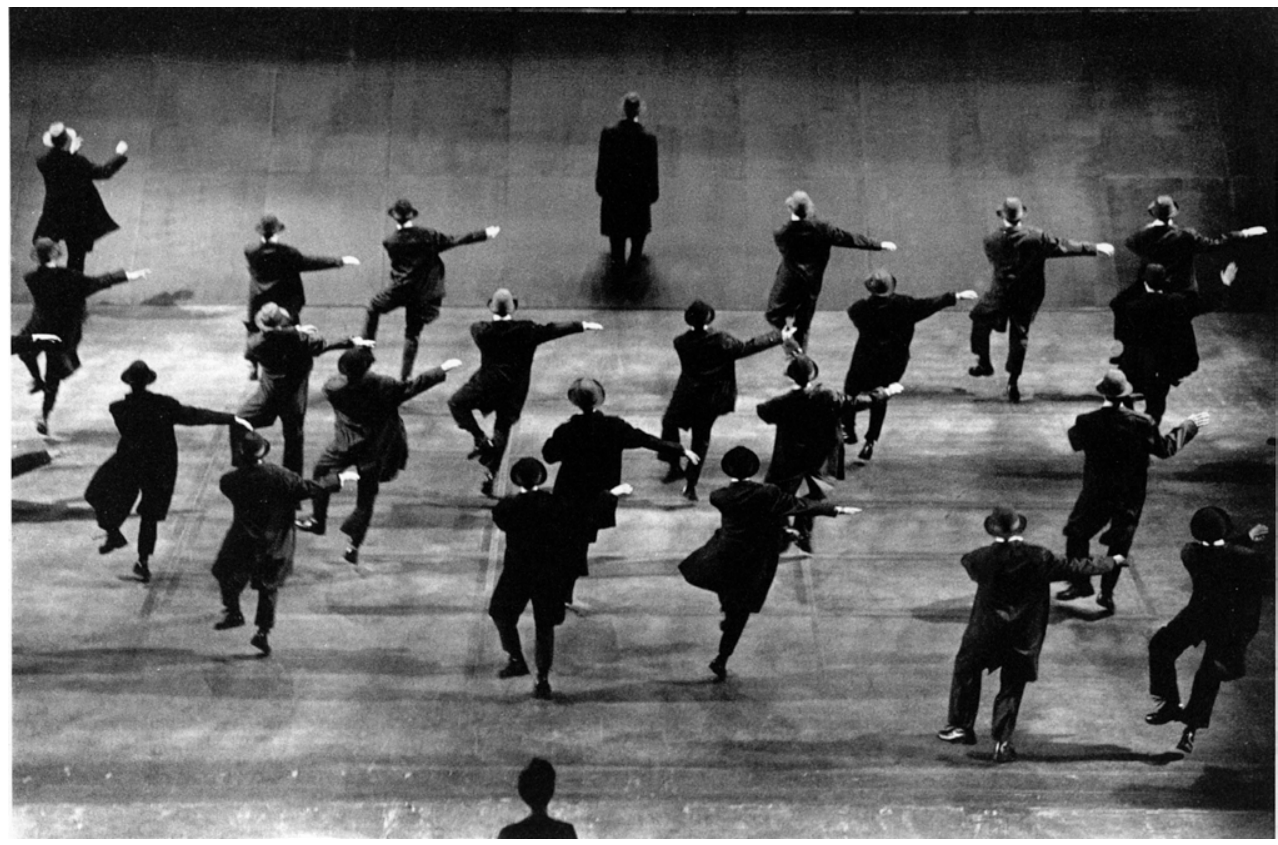

Figure 7. Joe, photographed by Michael Slobodian during the 1989 performance at the Place des Arts, Montreal (image courtesy of the Fondation Jean-Pierre Perreault, Montreal)

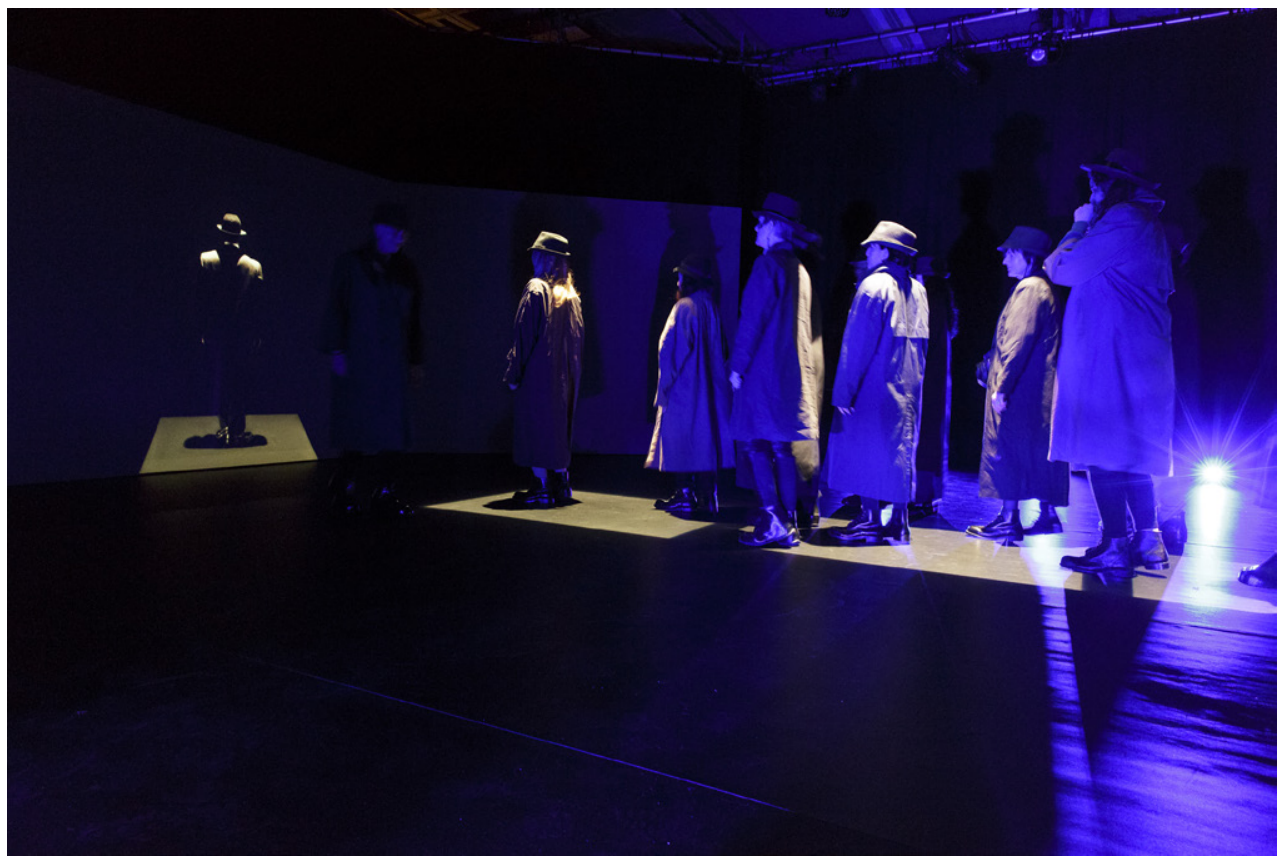

igure 8 . Artists and museum staff photographed in the Studio during a test visitor performance of Joe (Musées de la civilisation. Photo: Jérémie LeBlond-Fontaine - Icône) 
Up to 15 visitors at a time are invited into the Studio ${ }^{7}$ and, with the help of artists and/ or MCQ on-site staff, each don (reproductions of) the boots, coats and hats worn by the original 15 dancers in the play. Visitors then receive short pre-recorded instructions provided by Giselle Chagnon, choreographer and long-time associate of the late Jean-Pierre Perreault. Once everyone is 'coached' into reproducing the choreography, the performance is filmed and progressively shown on a giant screen located at the exit of the exhibition. Visitors are then able to see the (two-minute) choreography in which they have taken part - and, by extension, through which they have helped preserve the memory of the play through enactment.

Using high quality digital technology, the performance of visitors is gradually superimposed on the original video of Joe. Visitors can thus realise the accuracy with which they were able to reproduce the dance movements of the original cast - often surprisingly close to the original choreography!

The second type of activity that takes place in the Studio is on-site choreography residencies. Organized throughout the exhibition's lifespan, residencies aim to create/generate/ invite new forms of interaction among the museum visitor and the dancers and artists of the performing arts community and/or industry. Artists and creators in residence are invited to use the Studio as their research-creation workshop, allowing the museum-goer to witness firsthand (and even participate in) the process through which dance is conceptualized and how bodily action becomes meaningful and a vehicle for social memory. ${ }^{8}$ The creation sessions and dance performances that emerge from the residencies will then be recorded and kept in the Museum collections (as digital or material recordings) in an effort to preserve the traces of an ethnography of creativity and/or the creative process related to this art.

\section{Curating in action}

Over the years, the Musées de la civilisation have often dealt with popular culture and elements of intangible heritage, including songs (I Hear You Singing, 1995), television broadcasts (Quebec Soaps, 1996), cinema (Quebec Cinema - The Whole Story, 2006), and music (Riff- When Africa Got us Groovin', 2010). These projects explored the myriad ways in which collective memory and imagination can best be preserved and disseminated to the community. Each exhibition was an opportunity to highlight objects from the Quebec national collections (under the care of MCQ) which have been steadily accumulating, but relatively little used over the years. In Michel Tremblay (2012), however, not a single object was used from the many available artefacts from the plays (costumes, set furniture, etc.). Instead, the exhibition space was transformed into an immersive environment. Diane Landry - Correspondences went further, transforming the museum into a veritable place for creativity and dialogue among artists, museum staff, and visitors. Rebel Bodies has pursued this idea of the exhibition as a performance.

As manifestations of $\mathrm{ICH}$, the performing arts present not only challenges but also possibilities for museums. Museums have traditionally organized their collections based on materiality (e.g., industrial, cultural, artistic, and craftsmanship), and have classified them chronologically. While material culture can be documented, providing a sense of the ways in which objects have been understood over time and space, for all intents and purposes most material objects in the museum serve to highlight the past. $\mathrm{ICH}$, on the other hand, cannot be approached using traditional principles of collection-making, for its essentially transformative nature, which encompasses several types of performance, calls for new forms of curatorship to further bridge the space between museums and creators.

The memory of a performance is multilayered. It is at once material (costumes, space, scene, photos, video clips, notations), acoustic (music, sounds created by dancers), physical (bodily action, relationship with audience), dynamic (live interaction between dancers), and social (created in a specific environment and based on a particular worldview). Performing arts such as dance present at least two main challenges in terms of heritage preservation. Firstly, dance is an ephemeral and irreversible art form, and its meaning almost entirely depends on efforts by other individuals to preserve its memory through re-enactment or re-interpretation. Secondly, in recent years, and as an offshoot of digitization, the creative process in performing arts is often entirely digital - thus, entirely intangible (though digital recordings remain material artefacts). Dance, like language, never stops transforming and evolving. Like living organisms, 
choreographic works metamorphose, and, as performances, their re-enactment is a vehicle for - and embodiment of - social memory. But could this 'prismatic' way of collecting be feasible for all (object-based) museum collections? The work of historian and culture theorist Aby Warburg (1866-1929) provides insight into addressing such a question.

In 1927, Warburg created the Mnemosyne Atlas, made of 63 panels and over 1,000 reproductions of artworks, cards, manuscript pages, and newspapers clips. Akin to twodimensional cabinets of curiosities and improvised collages, these panels come across as surprisingly modern for their prismatic vision defied chronology and genres while still stringing together meaning (Johnson 2013). This is not so different from hypertext. Such an 'archaeology' of knowledge and creativity is echoed in the current thinking of art historians and performance artists. Georges Didi-Huberman's revisiting of Warburg in the Atlas exhibition recreated Warburg's Panel 42 on the theme of the Pietà, making an in-depth use of the image's ghostly nature and its ability to bridge reanimation, dread, repetition, variation, repression, and transformation (Didi-Huberman 2011). This approach highlights the importance of the recurrance and persistence of meaning in renewing the interpretation of an object. It tells us more about ourselves (our society/civilization), than what we can usually say about them.

The Montreal-based Fondation Jean-Pierre Perreault has recently taken an interest in preserving the choreographic repertoire of dancer Jean-Pierre Perreault by creating 'choreography boxes'. These are designed to contain everything that is required to perform and 're-enact' his work, including notes, images, music, stage designs, interviews with artists, recordings, reviews, and texts (see Fontaine 2012). Such initiatives help raise key issues with regard to the responsibility and ability of museums to preserve the $\mathrm{ICH}$ related to the performing arts, or even to enrich old collections with material relevant to highlighting $\mathrm{ICH}$. This is particularly significant for those museums whose mission is to preserve and highlight the societal heritage of society from a thematic perspective, like MCQ. Performing arts cannot survive the traditional organizational logic of museum collections and management, essentially organized to preserve and curate material artefacts. This is quite the opposite to the very essence of the performing arts, which continuously follow - and evolve along with - societal changes. While contemporary creators have on occasion been invited to create works of art based on objects from museum collections, Rebel Bodies addresses a different challenge: that of creating and curating on-site based on a 'living' body of work. While Diane Landry's installations dealt with the impulse of creating and expressing social meaning by linking a (local) ethnographic object with contemporary art installations, Rebel Bodies makes visitors and artists active participants in the making of the Museum as a place of performance and creativity. This also allows us to record and archive the memory by using new technologies such as the visitor performances that take place in the Studio.

$M C Q$, like other heritage institutions, to quote Barbara Kirshenblatt-Gimblett (2006:370), has developed as a place in which 'stories come first, and objects follow'. In Rebel Bodies, this idea is applied quite literally, letting artists themselves chose objects from MCQ collections in accordance with the narratives that they co-develop with museum staff. Such a deliberate choice by the Museum is meant to highlight how sets of artists today choose whether to integrate objects from the past (or those objects they themselves regard as significant to highlighting contemporary dance) into their creative process. The few objects that actually made the exhibition, mostly archives, likewise highlight the too few links that subsist - in Canada at least - between the community of artists and the material culture used by previous generations of creators.

The exhibition also raises another issue: how ill-equipped the performing arts community can sometimes be to best preserve the material culture related to past and current projects. Indeed, regular interviews and meetings with current partner artists and creative agencies often emphasize the lack of space, time and expertise for preserving all the material of their art, even for recycling purposes for possible use in future projects. Similarly, museums are also often ill-equipped to ensure the re-enactment of the performing arts. This is mainly due to lack of space or technical support and material to recreate on-site performances. Collaborative projects such as Rebel Bodies bring together artists/museum staff and visitors in an effort to maintain and find sustainable solutions to the delicate balance between a need to re-enact performances - to ensure the survival of their memory - and a need to highlight museum collections that may be relevant to the performing arts. 
The example of Stravinsky's The Rite of Spring in the project has been key in illustrating the above balance between re-enactment and material collections. It first shows how a few scattered documents and forgotten objects can lead to a surprising story as these are reconstituted (through object biographies made available by the Museum) and reinterpreted (by partner artists). The single display of costumes and props could not, if ever, in this case fulfil the role of experiencing the oeuvre and witnessing its many reinterpretations as vehicles of the memory of the original piece. Indeed, with the help of technology such as digital video captures, sound effects, and so on, the zone dedicated to The Rite in Rebel Bodies goes far beyond what artefacts displayed alone can usually do, that is to allow the visitor to experience the past (albeit momentarily). Each of the reinterpretations shown on screen embodies the memory of the original piece. In 1959, choreographer Maurice Béjart's then-radical new version revisited the play with striking modernity by emphasizing themes of archaism, victimhood, and sacrifice. It was subsequently followed by Pina Bausch's reinterpretation in 1975, Marie Chouinard's re-envisioned animal dimension in 1993 and Angelin Preljocaj's highly sexualized version in 2001. Sasha Waltz recently took on the challenge in Paris in 2013 to mark the play's one hundredth anniversary. Throughout Rebel Bodies, visitors can also to listen to the musical score of The Rite, recorded in 2008 at the Opéra National in Paris with the Mariinski Orchestra conducted by Valéry Gergiev.

Museums play many roles. Providing a stage for choreographers, dancers, and creators of all disciplines in a joint effort to create meaningful projects and curate them in situ is, we believe, one such role. Rebel Bodies is an organic exhibition in a constant state of flux; for all intents and purposes it is, in and of itself, an ethnographic artefact. There is also an international component to the exhibition. In a collaborative effort, artists, designers and researchers from Quebec, France, and the UK ${ }^{9}$ all worked closely to design the exhibition based on a general framework, making sure of its universal character through its topics, adaptation, and means of display. Since choreographic memory rests largely on film and video, the various digital platforms used in the exhibition space (digital screens, computer-generated shadow play, performance recordings of both visitors and artists, etc.) provide an underlying structure easily adaptable to other cultural contexts. This means that the exhibition at the Musée des Confluences in Lyon (autumn 2016) will be noticeably different from the one in Quebec City (2015). As the exhibition travels, the artists invited to create in the Studio will also change since each city will invite its own network of artists. As a result, the exhibition content - both in terms of the museum artefacts that artists may choose to integrate into their art as well as the recordings of the artists' and visitor's performance - will be different. This is meant to encourage meetings and collaborations between artists and communities as the project travels to various cities, namely by bridging Quebecois and French artistic communities.

One of the main challenges of such an international collaborative project has been the confinement of space. Indeed, many artists and choreographers involved in the projects expressed how dedicated spaces for creativity often go against the creative ambitions and thought processes of many creators, who usually prefer to freely explore and use all of the available architecture and spaces. As mentioned earlier in this article, Rebel Bodies is also a response to this issue, intended to show how the confinement of creativity within the strict boundaries of an exhibition space can also greatly lead to and encourage new forms of active and sustainable collaborations between artists and museum staff.

Of course, in additional efforts to increase the potential and use of all of the remaining available spaces in the Museum, MCQ staff worked with various choreographers in producing an international call for dance video projects that invited artists to submit performances that would take into consideration other museum spaces (besides the exhibition), their public areas, and/or material collections. The aim of this international call for contributions was to provide opportunities for artistic communities to revisit museum collections. This was meant to reactivate an interest in old collections by giving them a contemporary perspective. As such, selected objects will be brought to life and given new meaning. For providing new opportunities to access, share and exchange knowledge on museum collections is essential to museums today operating under principles of cultural democratization. And this is perhaps how museums best remain relevant. 


\section{Conclusion}

RebelBodies transcends the conventional museum-going experience, becoming a participatory on-site work-in-progress and a catalyst for enquiry on matters of performance and intangible cultural heritage. The project can be said to be grounded in a linguistic approach. Indeed, through Rebel Bodies the Museum enables a field of enquiry (the performing arts) to become subject (social phenomenon) and verb (mode of social action). The project explores the invisible and ephemeral nature of contemporary dance, seen as a vehicle of social memory. It challenges, and perhaps expands, the category of performing arts within the UNESCO framework on ICH to include contemporary dance. Like other forms of dance, contemporary dance is an inherited tradition and practice; one that embodies social memory - even folk-based traditions - through gestures. The exhibition aims to show visitors how the choreography of contemporary dance, as it has been understood and defined since the early twentieth century, is an emancipating art form that challenges - and can even shatter - cultural perceptions and assumptions.

Studies have emphasized the way in which 'performance in the museum often has value and resonance', underscoring how 'it can enhance the visitor's appreciation and critical understanding of the heritage in question' (Jackson and Kidd 2011:2; see also Bridal 2004). Rebel Bodies challenges the fundamental role of the museum as a place for collecting, documenting and exhibiting objects. It provides a framework for thinking about exhibition spaces as places of dialogue and creativity with the artistic community. Through the re-use of ethnographic material, namely video and photo archives where relevant, Rebel Bodies further tests the idea of the museum as a place of performance. This raises an interesting set of questions. In a context of economic restraint, how can (or should) museums contribute to both the preservation and development of contemporary $\mathrm{ICH}$ such as contemporary dance? This would in fact implicate the adapting of their archive, acquisition policy and collections management practice. It would also involve the need to create new guidelines and priorities for collecting and curating $\mathrm{ICH}$. Or should the preservation and curating of $\mathrm{ICH}$, particularly that which relates to bodily action and performance, be left to the industry and communities of artists that shape the performing arts?

Our enquiry readily follows from the specificity of both sectors: the museum is traditionally already equipped and prepared to preserve and continue developing meaning from the $\mathrm{ICH}$ related to the performing arts (musical scores, photographs, videos, costumes, decor, props, interviews with artists, and so forth). It may perhaps be better suited to curating action, in the sense of curating the tangible heritage related to movement and bodily action. On the other hand, the entertainment and performing arts sector is naturally organized and managed in such a way that it may be perhaps better positioned to ensure sustained and continuous reenactments of $\mathrm{ICH}$ related to contemporary dance, and therefore contribute to preserving its memory. In other words, it may perhaps be better suited to curate performances in action, in the sense of curating museum-based live choreographies. However, performing arts share little of the heritage preservation interests and methods as established and practised by museums. Conversely, the performing arts sector has little knowledge/awareness of the costs involved in the building and management of collections, and most museums likewise seldom dispose of adequate resources or knowledge, technical or otherwise, to re-enact works related to the performing arts. As an example, the MCQ holds in its permanent collections many artefacts relating to Quebec's entertainment heritage, including the costumes of many of the programmes broadcast on national television (Société Radio-Canada). And yet, like the majority of Canadian and Quebecois museums, the MCQ has neither the proper funding, mandate, nor even reflex to collect the actual broadcasts on video or in a digital format. Perhaps more importantly, it is ill-equipped for providing the means for in situ physical re-enactment. Finally, there is also the matter of knowledge sharing and exchange. Currently, there is little cohesion and no centralized database in Canada that documents and further bridges the sectors of the performing arts and entertainment, and museums. This means that their related $\mathrm{ICH}$ is never fully dealt with, documented, or curated by either sector.

With the above in mind, Rebel Bodies argues that it is not through simply one or the other sector, but rather through a partnership between museums and the performing arts industry and artists that contemporary dance - and its related $\mathrm{ICH}$ - can be best preserved 
and re-enacted. Rebel Bodies shows how a museum can (momentarily) transform itself into a platform for the sharing and exchange of knowledge and creativity; a place that promotes sustainable collaborations between the heritage and entertainment (the performing arts) sectors. Such intertwined partnerships provide the basis for a new model for sustainable development in culture where both sectors share and contribute to keeping ICH 'alive'.

Received 11 August 2015

Finally Approved 10 June 2016

\section{Notes}

1 Musées de la civilisation (MCQ) is a museum complex located in the heart of Old Quebec City, Canada. It includes the Musée de la civilisation, the Musée de la Place Royale, the Maison historique Chevalier, the Musée de l'Amérique francophone, and the Centre national de conservation et d'études des collections.

2 As noted by Barbara Kirshenblatt-Gimblett 2006:364), some museums have aimed to "extend ethnography to everyone, including oneself [...] [and apply] the idea that a solution to the problem of the West and the rest is integration: everyone's art in the art museum and all peoples in the museums of society and culture".

3 Common term is Francophone museology, musée de société ('museum of society') emerged as an expression and genre of museum in the 1990s in reference to inclusive heritage institutions, integrating practices and policies drawn from ecomuseums, site museums, as well as history and ethnography museums, in order to focus on exhibition making and civic participation (see Alcalde i Gurt et al. 2012; Desvallées and Mairesse 2011:628; Drouguet 2015).

4 Inaugurated in Quebec City in 1988, the Musées de la civilisation introduced in the North American context a new genre of museum (and a new form of organizational structure) informed by principles of cultural democratization and interdisciplinarity (see, e.g., Arpin 1992; Bergeron 2009). MCQ's approach, considered a radical departure from traditional museum practice at the time, marked a new way of thinking about objects that highlights the distinction between research-based (or collections-based) and theme-based museums. In the latter, the role of objects has been reconfigured in the service of exhibition making.

5 Other exhibitions tested such an approach, including 26 objets en quête d'auteur/26 objects in search of authors (2004) and 7 pêchés: quand les objets parlent au diable/ 7 Sins. 7 New Takes from the Museum (2009), both presented at the Musée de la civilisation.

6 We are grateful to the artists who participated in, and contributed to, the making of each unit: Margie Gillis (Natural bodies), Louise Lecavalier (Virtuoso bodies), Victor Quijada (Urban bodies), Martine Époque \& Denis Poulin (Multi-bodies), Daniel Léveillé (Political bodies) and France Geoffroy (Atypical bodies).

7 The Studio is equipped and prepared to meet the necessary standards in terms of disability and universal accessibility.

8 Calls for participation were published throughout various web-based platforms. Various artists responded by presenting dance projects to be created into the Studio.

9 The London-based Bodydata Space also collaborated in the early stages of the project.

\section{References}

Alcalde i Gurt, G. Boya Busquets, J. and X. Roigé i Ventura (eds) (2012) Museums of Today: the New museums of society, Barcelona: Institut Català de Recerca en Patrimoni Cultural. 
Alivizatou, M. (2008) 'Contextualising Intangible Cultural Heritage in Heritage Studies and Museology', International Journal of Intangible Heritage, 3 43-54

(2011) 'Intangible Heritage and the Performance of Identity', in Jackson, A. and J. Kidd (eds) Performing Heritage. Research, Practice and Innovation in Museum Theatre and Live Interpretation, 82-93, Manchester: Manchester University Press

(2013) Intangible Cultural Heritage and the Museum. Left Coast Press.

Arpin, R. (1992) Le Musée de la civilisation : concept et pratiques, Quebec: Éditions Multimondes.

Bal, M. (2011) 'Exposing the Public', in S. Macdonald (ed.) A Companion to Museum Studies, 525-542, Chichester: Blackwell

Bell, C. (1992) Ritual Theory, Ritual Practice, Oxford: Oxford University Press

Bergeron, Y. (2009) 'Le « complexe » des musées d'ethnographie et d'ethnologie au Québec, 1967 - 2002', Ethnologies 24 (2) 47-77.

Bridal, T. (2004) Exploring Museum Theatre, Walnut Creek, CA: AltaMira Press

Christidou, C. (2012) Does 'pointing at' in museum exhibitions make a point? A study of visitors' performances in three museums for the use of reference as a means for initiating and prompting meaning-making. Unpublished PhD thesis. University College London.

Connerton, P. (1989) How Societies Remember, Cambridge: Cambridge University Press.

Côté, M. (2012) Vers une société des savoirs: complexité et dynamisme, paper presented at the CEFRIO conference, Montreal (12 June).

Desvallées, A. and F. Mairesse (eds) (2011) Dictionnaire encyclopédique de muséologie, Paris : Armand Colin.

Didi-Huberman, G. (2011) Atlas ou le gai savoir inquiet. L'Oeil de l'histoire, 3, Paris: Les Éditions de Minuit.

Drouguet, N. (2015). Le Musée de société : de l'exposition de folklore aux enjeux contemporains, Paris : Armand Colin.

Fontaine, A. (2012) 'Regards vers le passé, élans vers l'avenir. Fondation Jean-Pierre Perreault : interview' Jeu : revue de théâtre 142(1) 137-143.

Frey, B. S. and B. Kirshenblatt-Gimblett. (2002) 'The Dematerialization of culture and the Deaccessioning of Museum Collections' Museum International 54 (4) 58-63.

Goffman, E. (1959) The Presentation of Self in Everyday Life, New York: Doubleday

Golding V. and W. Modest (eds) (2013) Museums and Communities: Curators, Collections and Collaboration, London: Bloomsbury.

Gonseth, M.-O. and N. Yasgi (2002) Le Musée Cannibale, Neuchâtel: Musée d'ethnographie.

Greenfield, L. (1998) Airborne: the New Dance Photography of Lois Greenfield, San Francisco, CA: Chronicle Books.

Hooper-Greenhill, E. (2000) Museums and the Interpretation of Visual Culture, London: Routledge. 
Kirshenblatt-Gimblett, B. (2006) 'Reconfiguring Museums: an afterword', in C. Grewe (ed), Die Schau des Fremden (Transatlantische historische Studien, Bd. 26), 361-376, Stuttgart: Franz Steiner Verlag.

Jackson, A. and Kidd, J. (eds) (2013) Performing Heritage: Research, practice and innovation in museum theatre and live interpretation, Manchester: Manchester University Press.

Johnson, C. (2013) Memory, Metaphor, and Aby Warbug's Atlas of Images, Ithaka, NY: Cornell University Press.

Karp, I., Kreamer C. M. and S. Levine (eds.) (1992) Museums and Communities: the Politics of Public Culture, Washington D.C.: Smithsonian Institution Press.

Kirshenblatt-Gimblett, B. (2006) 'Reconfiguring Museums: An Afterword' in C. Grewe, ed., Die Schau des Fremden: Ausstellingkonzepte zwichen Kunst, Kommerz und Wissenschaft. Transatlantische Historische Studien 26. Stuttgart: Franz Steiner Verlag.

Kreps, C. (2003) Liberating Culture: Cross-Cultural Perspectives on Museums, Curation and Heritage Preservation, London: Routledge.

(2009) 'Indigenous curation, museums, and the intangible cultural heritage', in Smith, L. and N. Akagawa (eds), Intangible Heritage, 193-208, London: Routledge.

Macdonald, S. (2011) 'Expanding Museum Studies: an introduction', in S. Macdonald (ed), Companion to Museum Studies, 1-12, Chichester: Blackwell

Osumare, H. (2013) 'Global Breakdancing and the Intercultural Body', in F. J. Korom (ed.), The Anthropology of Performance: a Reader, 260-271, Oxford: Willey and Sons.

Robertshaw, A. (2006) 'Live Interpretation', in Hems, A. and M. Blockley (eds), Heritage interpretation, 41-54. New York: Routledge.

Ruggles, F. and Silverman, H. (eds) (2009) Intangible Heritage Embodied. New York: Springer.

Sandell, R. (1998) 'Museums as Agents of Social Inclusion', Museum Management and Curatorship 17 (4) 401-418

Schechner, R. (2003 [1988]) Performance Theory (revised edition), London: Routledge.

Shelton, A. A. (2011) 'Museums and Anthropologies: practices and narratives', in S. Macdonald (ed), A Companion to Museum Studies, 64-80, London: Blackwell.

Simon, N. (2010) The Participatory Museum, Santa Cruz, CA: Museum 2.0.

Smith, L. (2006) Uses of Heritage, London: Routledge.

Taylor, J. (1998) Paper Tangos, Durham, NC: Duke University Press.

UNESCO (2003) Convention for the Safeguarding of Intangible Cultural Heritage, Paris

Viau-Courville, M. (2012) 'Diane Landry et l'objet vernaculaire: de la mouvance des objets au Musée de l'Amérique française' Material Culture Review/Revue de la culture matérielle 74-75 205-214 